KS.WOJCIECH NECEL SCHR

Wydział Prawa Kanonicznego

Uniwersytetu Kardynała Stefana Wyszyńskiego w Warszawie

\title{
WATYKAŃSKA DYKASTERIA \\ DS. INTEGRALNEGO ROZWOJU CZŁOWIEKA W SŁUŻBIE MIGRANTÓW
}

Treść: Wprowadzenie. - 1. Powstawanie i rozwój instytucji Stolicy Apostolskiej służących dobru duchowemu ludzi w drodze. - 2. Od motu proprio Pastoralis migratorum cura z 1969 r. do instrukcji Przyjęcie Chrystusa w uchodźcach i przymusowo przesiedlonych z 2013 r. - 3. Idee przewodnie motu proprio Humanam progressionem z 2016 r. - 4. Postanowienia Statutu Dykasterii ds. Integralnego Rozwoju Człowieka. - 5. Sekcja migrantów i uchodźców w nowej Dykasterii. - Zakończenie.

\section{Wprowadzenie}

Kościół Chrystusowy od początku swojego istnienia nie był obojętny wobec ruchliwości wiernych, ale systematycznie badał to zjawisko i wobec poszczególnych kategorii migrujących rozwijał adekwatną opiekę duszpasterską. Troska ta znajdowała oparcie w coraz dojrzalszych rozwiązaniach kanonicznych i specjalnych strukturach. W dziejach Kościołów diecezjalnych i wspólnot parafialnych obserwuje się powstawanie organicznych rozwiązań aż po dzisiejszą misję duszpasterską odpowiadającą potrzebom przybyszów, uciekinierów i uchodźców oraz instytucję kapelanów portów lotniczych i morskich. Konstytutywne elementy missio cum cura animarum oraz posługi kapelana wskazane są w instrukcji Papieskiej Rady ds. Duszpasterstwa 
Migrantów i Podróżujących Erga migrantes caritas Christi ${ }^{1}$, w instrukcji Papieskiej Rady ds. Duszpasterstwa Migrantów i Podróżujących i Papieskiej Rady Cor Unum pt.: Przyjęcie Chrystusa w uchodźcach i przymusowo wypędzonych ${ }^{2}$ oraz w innych instrukcjach Papieskiej Rady ds. Duszpasterstwa Migrantów i Podróżujących dotyczących poszczególnych kategorii ludzi w drodze $e^{3}$.

Duszpasterska troska o ludzi w drodze z natury swojej wymaga współpracy pomiędzy episkopatami krajowymi oraz między nimi a Stolicą Apostolską, wreszcie pomiędzy Kościołem katolickim a innymi podmiotami prawa międzynarodowego, jak również pomiędzy poszczególnymi wyznaniami chrześcijańskimi i wspólnotami religijnymi. Zaproponowana przez Ojca Świętego Franciszka nowa Dykasteria Kurii Rzymskiej zdaje się, w duchu soborowej Konstytucji o Kościele w świecie współczesnym Gaudium et spes, czynić zadość tym oczekiwaniom.

\section{Powstawanie i rozwój instytucji Stolicy Apostolskiej służących dobru ludzi w drodze}

Początków międzydiecezjalnych i ogólnokościelnych prób rozwiązywania problemów duszpasterstwa ludzi w drodze należy szukać w trosce o los francuskich emigrantów i uciekinierów z końca XVIII i początku XIX wieku4 ${ }^{4}$ Starania te zostały zintensyfikowane w XIX i na początku XX wieku w kontekście zjawiska przymusowych

\footnotetext{
${ }^{1}$ Papieska Rada Ds. Duszpasterstwa Migrantów i Podróżujących, Instrukcja Erga migrantes caritas Christi (dalej EMCC), Lublin 2008.

${ }^{2}$ Papieska Rada ds. Duszpasterstwa Migrantów i Podróżujących, PapieSKA RADA COR UNUM, Instrukcja Przyjęcie Chrystusa w uchodźcach i przymusowo wypędzonych (dalej Przyjęcie Chrystusa), Watykan 2013.

${ }^{3}$ Np.: Dyrektywy dla Katolickiego Duszpasterstwa Lotnictwa Cywilnego (1995) (Direttive per la Pastorale Cattolica dell'Aviazione Civile); Wskazania dotyczące Duszpasterstwa Turystyki (2001) (Orientamenti per la Pastorale del Turismo); Wskazania dotyczące Duszpasterstwa Cyganów (2006) (Orientamenti per la Pastorale degli Zingari); Wskazania dotyczące Duszpasterstwa Drogi (2007) (Orientamenti per la Pastorale della Strada).

${ }^{4}$ PIUs XII, Konstytucja apostolska Exsul Familia (dalej EF), Studia Polonijne 4(1981), s. 19-21.
} 
przesiedleń z Afryki do Ameryki Płn. i masowego handlu ludźmi ${ }^{5}$ oraz nasilającej się migracji zarobkowej z Europy do obu Ameryk.

W panoramie troski Stolicy Apostolskiej o ludzi w drodze szczególne miejsce przypada biskupowi Piacenzy, Giovaniemu Baptiście Scalabriniemu (1839 - 1905). On pierwszy zwrócił uwagę na to, że duszpasterstwo migrantów, wśród wielu koniecznych instrumentów kanonicznych, potrzebuje również centralnej instytucji monitorującej przepływ ludności pomiędzy diecezjami, państwami i kontynentami. W petycji Pro emigrantis catholicis ${ }^{6}$ skierowanej do Stolicy Apostolskiej zaproponował powołanie komisji papieskiej zajmującej się apostolstwem migrantów. Instytucja ta, oprócz rozwiązywania problemów duszpasterstwa ludzi w drodze, miałaby również zapobiegać rodzącym się napięciom nacjonalistycznym w środowiskach imigracyjnych oraz nie dopuszczać do podziałów wielonarodowej i wielojęzycznej katolickiej wspólnoty osiedlających się na terenie danego Kościoła diecezjalnego ${ }^{7}$.

Uporządkowania ogólnokościelnej działalności duszpasterskiej na rzecz migrujących podjął się Pius X. W Kurii Rzymskiej przy Kongregacji Konsystorialnej w 1912 r. powołał Biuro ds. Problemów Migracji. Zadaniem Biura było badanie potrzeb duchowych migrujących katolików oraz rozwiązywanie napotkanych problemów

Dramatyczne przeżycia I wojny światowej znalazły swój wyraz między innymi w zaangażowaniu Stolicy Apostolskiej na rzecz uchodźców wojennych i ludności cywilnej przesiedlonej z racji działań wojennych ${ }^{9}$. W tym okresie w celu ściślejszej współpracy

\footnotetext{
${ }^{5}$ Tamże, s. 17.

${ }^{6}$ G.B. Scalabrini, Memoriale Pro emigrantibus catholicis z 4.05 .1905 r., w: S. Tomasi, G Rosoli, Scalabrini e le migrazioni moderne. Scriti e carteggi, Torino 1997, s. 233.

${ }^{7}$ Por. EMCC 31.

${ }^{8}$ Tamże.

${ }^{9} \mathrm{~Np}$. Kongregacja Konsystorialna w trosce o dobro duchowe migrantów w czasie I wojny światowej i wsparcie materialne dla instytucji katolickich opiekujących się nimi zaleciła, by każdy proboszcz raz w roku zamiast Mszy św. w intencji parafian, odprawił Mszę w intencjach papieża, a stypendium przeznaczył na dzieła opieki
} 
pomiędzy poszczególnymi episkopatami oraz między nimi a Stolicą Apostolską, w poszczególnych episkopatach krajowych powoływano protektorów migrantów ${ }^{10}$.

Fenomen migracji ogarniający na przełomie XIX i XX wieku coraz liczniejsze rzesze uchodźców, wypędzonych i poszukujących pracy, stawiał Kościół przed nowymi wyzwaniami. Wymagały one nowych regulacji umożliwiających pasterzom Kościoła podejmowanie rodzących się zadań. W Kurii Rzymskiej coraz bardziej słyszalne były głosy domagające się powołania centralnej instytucji koordynującej apostolskie zabiegi Kościołów lokalnych wobec przybyszów niezależnie od ich religii, wyznania i narodowości czy motywów migracji. W jakimś stopniu znalazły one swoje odbicie w Kodeksie Pio-Benedyktyńskim z 1917 roku $^{11}$.

Po II wojnie światowej troska Kościoła o adekwatną opiekę religijną i społeczną nad każdą z kategorii ludzi w drodze przybierała, zarówno w diecezjach, jak i na szczeblu centralnym Kościoła powszechnego, coraz bardziej instytucjonalny charakter. W 1946 r. Pius XII powołał przy Sekretariacie Stanu Ufficio Migrazione, składający się z dwóch sekcji: ds. migracji dobrowolnej oraz ds. migracji przymusowej ${ }^{12}$.

Instytucjonalna forma troski o ludzi w drodze w sposób organiczny została zaproponowana przez Piusa XII w konstytucji apostolskiej „Exsul Familia” z 1952 r. Według dyspozycji kanoniczno-duszpasterskich zawartych w II części konstytucji, z ramienia Stolicy

nad emigrantami. Po zakończeniu wojny Benedykt XV zaproponował biskupom Kalabrii utworzenie patronatów w celu niesienia pomocy włoskim emigrantom.

${ }^{10}$ Dla dobra duchowego migrantów włoskich powołał specjalnego prałata, który wolny od zajęć w diecezji miał za zadanie animować duszpasterstwo w języku włoskim poza terytorium Italii. Do jego obowiązków należał również dobór misjonarzy migrantów i opieka nad nimi. W 1921 r. ordynariusz Kolonii został mianowany protektorem istniejącego już od 1904 r. dzieła opieki nad emigrantami niemieckimi, zamieszkującymi we Włoszech i w innych państwach Europy Zachodniej , a cztery lata później również nad emigrantami niemieckiego pochodzenia i mówiących językiem niemieckim, którzy mieszkali w krajach Europy Wschodniej i poza Europą.

${ }^{11}$ Por. W. Necel, Prawo migranta do specjalnego duszpasterstwa, Warszawa 2012, s. 37-38.

12 Por. EF s. 36. 
Apostolskiej za migrantów w Kościele była odpowiedzialna Kongregacja Konsystorialna, której przysługiwało „prawo badania i przygotowywania wszystkiego, co przyczynia się do duchowego dobra emigrantów obrządku łacińskiego"13. Istotnym jej zadaniem była również troska o kapłanów obrządku łacińskiego, którzy podejmowali pracę $\mathrm{w}$ duszpasterstwie na rzecz ludzi $\mathrm{w}$ drodze $\mathrm{e}^{14}$. $\mathrm{W}$ tak zakreślonym dziele Kongregacja Konsystorialna współpracowała z pozostałymi dykasteriami Kurii Rzymskiej, a nade wszystko z Kongregacją Kościołów Wschodnich oraz Kongregacją Rozkrzewiania Wiary ${ }^{15}$.

W czasie prac II Soboru Watykańskiego Ojcowie Soboru, przy zastosowaniu zasady pomocniczości, zobowiązali poszczególne Konferencje Biskupów do stałego badania zjawiska ruchów ludności na swoim terenie i przesyłania rocznych raportów do Kurii Rzymskiej. Po Soborze zgodnie ze wskazaniami Stolicy Apostolskiej poszczególne Konferencje zostały zmobilizowane do podejmowania adekwatnej opieki duszpasterskiej dla migrujących oraz do współpracy, tak aby „Wspólnymi siłami zaradzić pieczołowicie duchowej opiece nad migrantami przy pomocy odpowiednich środków i organizacji (...)"16.

Wskazania Soboru Watykańskiego II i posoborowe dokumenty dotyczące duszpasterstwa ludzi w drodze stanowią tezy teologii ruchów migracyjnych oraz ukierunkowują strukturę kanonicznych rozwiązań problemów związanych z migracją, przez co nadają szczególną wagę znaczeniu mobilności wewnątrz komunii Kościoła ${ }^{17}$. „Przyjęcie obcokrajowca (...) pozostaje (...) stałą pieczęcią Kościoła Bożego",

\footnotetext{
${ }^{13}$ EF I, $1,1-2$.

${ }^{14}$ Tamże, I 1 - 8. Od Kongregacji kapłani ci otrzymywali między innymi: pozwolenie na wyjazd do pracy wśród migrantów w krajach zamorskich, zezwolenie na inkardynację do diecezji, w której będą sprawowali duszpasterstwo na rzecz migrantów oraz zgodę na ewentualne przejście do pracy w duszpasterstwie emigracyjnym w innym kraju.

${ }_{15}$ Tamże, I, 1 par. 1

${ }^{16}$ Sobór Watyкański II, Dekret o pasterskich zadaniach biskupów w Kościele Christus Dominus, nr 18.

${ }^{17}$ Por. J. BAKAlARz, Misjonarz migrantów w prawodawstwie powszechnym Kościoła, Poznań 1992, s. 61-76.
} 
który jest „niejako naznaczony powołaniem do wygnania, do diaspory, do rozproszenia wśród kultur i wspólnot etnicznych, jednak nigdy nie utożsamia się $\mathrm{z}$ żadną $\mathrm{z}$ nich. W przeciwnym razie przestałby być tą pierwociną i znakiem, zaczynem i proroctwem Królestwa powszechnego oraz wspólnotą, która przyjmuje każdą istotę ludzką, bez różnicy osób czy narodów. Przyjęcie obcokrajowca należy zatem do samej natury Kościoła i świadczy o jego wierności Ewangelii”"18.

\section{Od motu proprio Pastoralis migratorum cura z 1969 r. do instrukcji Przyjęcie Chrystusa w uchodźcach i przymusowo przesiedlonych z 2013 r.}

Soborowa troska o migrujących znalazła swoje skonkretyzowanie w motu proprio Pawła VI Pastoralis migratorum cura z 15.08.1969 r. Zdaniem Ojca Świętego z nauczaniem soborowym trzeba zgodnie na nowo zorganizować duszpasterstwo ludzi w drodze i zakreślić zakres odpowiedzialności na poszczególnych szczeblach pastoralnej struktury Kościoła oraz zdefiniować rolę Stolicy Apostolskiej w tak prowadzonym dziele misyjnym ${ }^{19}$.

W tym duchu Kongregacja Biskupów w instrukcji De pastorali migratorum cura z 22.08.1969 r. potwierdziła, że z woli Pawła VI, do niej należy „kierowanie, zarządzanie, koordynowanie i prowadzenie tego wszystkiego, co dotyczy opieki duchowej nad wiernymi obrządku łacińskiego, którzy dokądkolwiek emigrują”. Obowiązek ten dzieli ona „z Kongregacją Kościołów Wschodnich i Kongregacją Ewangelizowania Narodów, gdy idzie o tereny podległe jednej z tych Kongregacji"20.

W DPMC dokonano również relektury terminu „migracja” i poszerzono go o nowe kategorie ludzi w drodze. Zgodnie z konstytucją

\footnotetext{
${ }^{18}$ EMCC 22.

${ }^{19}$ PaweŁ VI, Motu proprio Pastoralis migratorum cura, Studia Polonijne 4(1981), s. $59-60$.

${ }^{20}$ Kongregacja Biskupów, Instrukcja De pastorali migratorum cura (dalej: DPMC), Studia Polonijne 4(1981), art. 16, par. 1.
} 
apostolską Pawła VI Regimine Ecclesiae Universae z 15.08.1967 r. ${ }^{21}$, w De pastorali migratorum cura Kongregacji Biskupów przydzielono „Rady i Sekretariaty: dla emigracji, dla dzieł apostolatu morskiego, lotniczego i ludów koczowniczych"22. W realizacji tych zadań Kongregacja Biskupów winna współpracować z Kongregacją ds. Zakonnych i Instytutów Świeckich oraz z Sekretariatami ds. Jedności Chrześcijan, niechrześcijan i niewierzących oraz brać udział w tych wszystkich poczynaniach „które wydają się pożyteczne dla grup migrantów każdej wiary"23.

W ostatnich dekadach XX wieku proces podejmowania centralnej odpowiedzialności za migrujących przy jednoczesnym stosowaniu zasady pomocniczości nabiera szczególnego dynamizmu. W motu proprio Apostolicae caritatis Pawła VI następuje dalsza reorganizacja organów Stolicy Apostolskiej odpowiedzialnych za ludzi w drodze. Została wówczas powołana Papieska Komisja ds. Duszpasterstwa Migrantów i Turystów podległa Kongregacji Biskupów ${ }^{24}$ i po raz kolejny poszerzono termin „ludzi w drodze”, obejmując nim także turystów ${ }^{25}$. Odtąd Papieska Komisja ds. Duszpasterstwa Migrantów i Turystów w zależności od rodzaju migracji zawierała: sekcje dotyczące szeroko rozumianego apostolatu migrantów, uchodźców

\footnotetext{
${ }^{21}$ PAweŁ VI, Konstytucja apostolska Regimini Ecclesiae Universae, art. 52: „Kongregacji Episkopatu przydziela się Rady i Sekretariaty: dla Emigracji, dla dzieł Apostolstwa morskiego, lotniczego i ludów koczowniczych”, w: Ustrój hierarchiczny Kościoła (red. M. Sitarz, W. Kacprzyk), Lublin 2006, s. 166 - 196.

${ }^{22}$ DPMC art. 16 par. 4.

${ }^{23}$ Tamże.

${ }^{24}$ PaweŁ VI, Motu proprio „Apostolicae caritatis”, Studia Polonijne 4 (1981), s. 87: „Kościół katolicki powodowany apostolską miłością, kierował swoją troskliwą opiekę ku dostarczeniu swoim dzieciom tych środków, zwłaszcza duchowych, które zdawały się postulować szczególne okoliczności, dotyczące ludzi, rzeczy i czasów”. Jednak w ostatnim czasie ze względu na łatwość podróżowania, wielokierunkowość migracji oraz prognozowane natężenie ruchów ludności „trzeba zwrócić uwagę nie tylko na tych, którzy mieszkają w ustalonych granicach parafii (...) lecz także na tych, którzy z własnej woli lub na skutek jakiejś konieczności opuszczają miejsce zamieszkania”.

25 Tamże, s. 88.
} 
i wypędzonych oraz sekcje apostolstwa ludzi morza, apostolstwa podróżujących samolotami, apostolstwa koczowników, apostolstwa turystów i pielgrzymów oraz sekcję zajmującą się apostolstwem studentów zagranicznych.

Zgodnie z decyzją Pawła VI funkcję przewodniczącego Komisji pełnił każdorazowy Kardynał Prefekt Kongregacji Biskupów. Chociaż Papieska Komisja strukturalnie zależna była od Kongregacji, to „w załatwianiu powierzonych spraw cieszyła się pewną autonomią”. Jej zadaniem było analizowanie wspólnie z krajowymi Konferencjami Biskupów spraw związanych z wszystkimi kategoriami ludzi w drodze oraz podejmowanie decyzji dla ich dobra, a także monitorowanie wprowadzania proponowanych rozwiązań.

Kuria Rzymska jako zespół Dykasterii i Instytucji świadczy „pomoc biskupowi rzymskiemu w wykonywaniu przez niego najwyższej posługi pasterskiej dla dobra i w służbie Kościoła powszechnego i Kościołów partykularnych, przez co umacnia się jedność wiary i wspólnota Ludu Bożego, a także ożywia się misja właściwa Kościołowi w świecie"26. Kierując się tym przesłaniem, Jan Paweł II w konstytucji apostolskiej Pastor Bonus z dnia 28.06.1988 r. dostosował do aktualnych potrzeb strukturę, organizację pracy i odpowiedzialność poszczególnych organów Stolicy Apostolskiej. Według konstytucji Pastor Bonus organem Kurii Rzymskiej powołanym do rozwijania opieki duszpasterskiej nad poszczególnymi kategoriami ludzi w drodze oraz jej koordynowania była nowo powołana Papieska Rada ds. Duszpasterstwa Migrantów i Podróżujących. Jako spadkobierczyni Papieskiej Komisji ds. Duszpasterstwa Migrantów i Turystów ${ }^{27}$.

Analiza zaangażowania się Kościoła katolickiego na rzecz dobra duchowego ludzi w drodze została dokonana w instrukcji Erga migrantes caritas Christi z 3 maja 2004 r. W drugiej części dokumentu

\footnotetext{
${ }^{26}$ Jan PaweŁ II, Konstytucja apostolska Pastor bonus, w: Ustrój hierarchiczny Kościoła (red. M. Sitarz, W. Kacprzyk), Lublin 2006, art. 1.

${ }^{27}$ Tamże, art. 150.
} 
zakreślono na nowo między innymi obszar odpowiedzialności oraz zadań Papieskiej Rady ds. Duszpasterstwa Migrantów i Podróżujących ${ }^{28}$. $\mathrm{Na}$ fundamencie instrukcji Erga migrantes duszpasterska sytuacja uchodźców i wypędzonych wymagała uaktualnionych analiz i zdefiniowania specyfiki obecności tych kategorii migrantów w Kościele powszechnym, w Kościołach diecezjalnych oraz we wspólnocie parafialnej. Niepokoje polityczne i społeczne w pierwszych dwóch dekadach XXI wieku były swoistym katalizatorem wypracowania

${ }^{28}$ Według instrukcji Erga migrantes Papieska Rada winna zgłębiać wszystkie problemy związane z duszpasterstwem wszystkich kategorii migrantów. Świadczyć pomoc w zakresie organizowania w Kościele diecezjalnym skutecznego i własnego duszpasterstwa, również przez tworzenie w razie potrzeby odpowiednich struktur duszpasterskich dla uciekinierów, wygnańców oraz migrantów, z zachowaniem jednak odpowiedzialności poszczególnych Kościołów oraz poszczególnych organów Stolicy Apostolskiej. Na tak zakreślonym fundamencie „Erga migrantes” wylicza zadania Papieskiej Rady, która winna zapoznawać się z raportami dotyczącymi duszpasterstwa migrantów, przesyłanymi przez poszczególne Konferencje Episkopatu i odpowiednie struktury hierarchiczne wschodnich Kościołów katolickich. Zgodnie z kan. 34 KPK Papieska Rada może wydawać instrukcje sugerujące i wspierające działalność oraz programy dotyczące duszpasterstwa na rzecz migrantów. Zadaniem jej jest również ułatwianie wymiany informacji pomiędzy poszczególnymi Konferencjami Biskupów i właściwymi strukturami katolickich Kościołów wschodnich. Może ona też uczestniczyć w procesie przenoszenia duszpasterzy w celu podejmowania apostolatu na rzecz migrantów oraz wspierać, animować i harmonizować starania organów regionalnych i kontynentalnych, działających dla dobra migrujących. Papieska Rada ma prawo zapoznawać się z sytuacją migrantów i ich duszpasterzy w poszczególnych ośrodkach duszpasterskich i zwracać uwagę na erygowanie i rozwój właściwych struktur duszpasterskich. Zadaniem Rady jest również wspieranie instytutów zakonnych oraz instytutów świeckich i stowarzyszeń życia apostolskiego, które włączają się w troskę Konferencji Episkopatów i odpowiednich struktur wschodnich Kościołów katolickich o migrujących, z zachowaniem jednak kompetencji Kongregacji ds. Instytutów Życia Konsekrowanego i Stowarzyszeń Życia Apostolskiego oraz Kongregacji dla Kościołów Wschodnich. Wspólnie z Papieską Radą ds. Popierania Jedności Chrześcijan, Papieska Rada ds. Duszpasterstwa Migrantów i Podróżujących może inicjować i popierać współpracę ekumeniczną w obszarze duszpasterstwa emigracyjnego, zaś wspólnie z Papieską Radą ds. Dialogu Międzyreligijnego wspierać i inicjować działania mające na celu nawiązywanie dialogu z migrantami innych religii. 
przez Papieską Radę ds. Duszpasterstwa Migrantów i Podróżujących wspólnie z Papieską Radą Cor Unum instrukcji Przyjęcie Chrystusa w uchodźcach i przymusowo wypędzonych.

\section{Idee przewodnie motu proprio Humanam progressionem z 2016 r.}

W nowej Dykasterii Kurii Rzymskiej zgodnie z motu proprio papieża Franciszka Humanam progressionem z dnia 17.08.2016 r. i ze „Statutem Dykasterii ds. Integralnego Rozwoju Człowieka” aprobowanym przez Franciszka zostały „złączone kompetencje następujących Papieskich Rad: Papieskiej Rady Iustitia et Pax, Papieskiej Rady Cor Unum, Papieskiej Rady ds. Duszpasterstwa Migrantów i Podróżujących oraz Papieskiej Rady ds. Duszpasterstwa Służby Zdrowia".

Powołana Dykasteria przejęła między innymi kompetencje dotychczasowej Papieskiej Rady ds. Duszpasterstwa Migrantów i Podróżujących. Winna zatem objąć kategorie migrantów wskazane w konstytucji Exsul Familia oraz w instrukcjach: De Pastorali Migratorum Cura, Erga migrantes caritas Christi i Przyjąć Chrystusa. Wymienione wyżej dokumenty podkreślają, że we współczesnych ruchach migracyjnych trzeba wyróżnić tradycyjnie rozumianą migrację (np. ekonomiczną, polityczną, religijną) oraz współczesne kategorie migrantów którymi już wcześniej zajmowała się Papieska Komisja ds. Duszpasterstwa Migrantów i Turystów a później Papieska Rada ds. Duszpasterstwa Migrantów i Podróżujących. Powstała Dykasteria winna zająć się również bezpaństwowcami, ofiarami handlu ludźmi, przymuszanymi do niewolniczej pracy, kobietami i dziećmi poddawanymi przemocy seksualnej oraz dziećmi wojny. Wymienione kategorie ludzi są ściśle i na wieloraki sposób powiązane ze zjawiskiem migracji ekonomicznej lub politycznej.

Motu proprio Humanam progressionem papieża Franciszka zawiera klauzulę wyłączności tak, „aby to co zostało postanowione w motu proprio Humanam progressionem, było w mocy, niezależnie od jakichkolwiek przeciwnych rozporządzeń, nawet godnych szczególnego uwzględnienia (...) i weszło w życie 1 stycznia 2017 r.” W ten 
sposób Ojciec Święty wskazał między innymi, że utworzenie nowej Dykasterii nie jest tylko prostym przekazaniem zadań każdej z dotychczasowych czterech Rad jednemu organowi Stolicy Apostolskiej lub prostym zauważeniem wagi problemów, którymi każda z nich dotychczas się zajmowała. Papieżowi chodzi o zmianę jakościową. Każda z Rad wnosi do nowej Dykasterii swoje doświadczenie, wypracowane plany na przyszłość i organizację pracy oraz specjalistów. Dotychczasowe Rady często zajmowały się tymi samymi problemami, jednakże każda $\mathrm{z}$ nich podejmowała je w innym aspekcie. Podejmowane problemy dotyczyły wykluczonych i zepchniętych na margines, ludzi ubogich, schorowanych, bez środków do życia i podstawowych lekarstw, bezdomnych, zniewolonych migracją i nadludzką pracą, wykorzystywanych i słabszych. Decyzja Franciszka ma zintensyfikować troskę Kościoła o tak określonych potrzebujących i nieść im zintegrowaną wieloaspektową pomoc. W studium o nowej watykańskiej Dykasterii i jej zadaniach wobec ludzi w drodze trzeba podkreślić, że powołana Dykasteria ds. Integralnego Rozwoju Człowieka jest kolejnym ogniwem ewolucji centralnych organów Stolicy Apostolskiej zajmujących się problematyką ludzi w drodze i jednocześnie wyrazem praktycznej realizacji zasady pomocniczości w trosce o szczególne potrzeby uchodźców i wypędzonych.

W Humanam progressionem papież Franciszek wskazuje, że każdy migrujący, niezależnie od religii i wyznania, koloru skóry i języka, jest przedmiotem działalności Kościoła i mieści się w nurcie działalności misyjnej, która „wypływa z najgłębszej natury Kościoła” oraz „propaguje jego zbawczą wiarę, urzeczywistnia katolicką jedność (...) i podtrzymuje (...) apostolski charakter"29.

Papież Franciszek oparł zadania nowej Dykasterii na przesłaniu Soboru Watykańskiego II. „Kościół, w całym swoim istnieniu i działaniu, jest powołany do integralnego rozwoju człowieka w świetle Ewangelii”, a „rozwój ten dokonuje się przez niezmierzone dobra,

\footnotetext{
${ }^{29}$ Por. Sobór WAtykański II, Konstytucja dogmatyczna o Kościele Lumen gentium, nr 22-23.
} 
jakimi są sprawiedliwość, pokój i ochrona stworzenia" ${ }^{30}$. Zdaniem Ojca Świętego zabieganie Pasterzy Kościoła o integralny rozwój każdego człowieka prowadzić musi do każdej osoby stworzonej na obraz i podobieństwo Boga, a zepchniętej na margines życia społecznego, żyjącej w otchłani niesprawiedliwości w warunkach skrajnej nędzy i nieludzkiej pracy. Podejmując działania na rzecz ewangelicznych wartości Ojciec Święty wskazuje na konieczność nieustannego dostosowywania poszczególnych organów Stolicy Apostolskiej, tak „by mogły lepiej wychodzić naprzeciw oczekiwaniom mężczyzn i kobiet,

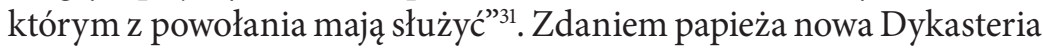
ma zająć się tym wszystkim, „co dotyczy zdrowia i dzieł miłosierdzia”, a w sposób szczególny „będzie kompetentna w kwestiach dotyczących migracji, potrzebujących, chorych i wyłączonych, marginalizowanych i ofiar konfliktów zbrojnych oraz katastrof naturalnych, więźniów, bezrobotnych i ofiar jakiejkolwiek formy niewolnictwa i tortur"32.

\section{Postanowienia Statutu Dykasterii ds. Integralnego Rozwoju Człowieka}

Wraz z motu proprio Humanam progessionem Ojciec Święty Franciszek zatwierdził i podpisał Statut powołanej przez siebie Dykasterii. Statut zawiera pięć artykułów, z których każdy dzieli się na kilka paragrafów. Poszczególne artykuły zatytułowane są kolejno; „Nazwa” (Nome), „Struktura” (Struttura) i „Cel, misja, działalność” (Compito, missione, attività), „Relacja do innych organizmów Kurii Rzymskiej” (Rapporto con membri della Curia e con Organismi connesi) oraz "Inne instytucje” (Altri Organismi).

Zaproponowana struktura Statutu zdaje się pełnić funkcję praktycznej interpretacji tego, co papież Franciszek chce osiągnąć likwidując cztery dotychczasowe Papieskie Rady i powołując w ich miejsce nową Dykasterię Kurii Rzymskiej.

\footnotetext{
${ }^{30}$ FranciszeK, Motu proprio Humanam progressionem (dalej HP); Fr ANCISZEK, Logika reformy, L'Osservatore Romano (PL), 38(2017), s. 32.

${ }^{31}$ Tamże.

32 Tamże.
} 
Zadaniem Dykasterii ds. Integralnego Rozwoju Człowieka jest wspieranie ogólnie rozumianego postępu oparte na przesłaniu Ewangelii i doktrynie społecznej Kościoła ${ }^{33}$. Według zamiarów papieża nowa Dykasteria w imieniu Stolicy Apostolskiej będzie podejmowała w sposób organiczny ogólnoświatowe problemy związane ze sprawiedliwością i pokojem, zdrowiem, dziełami miłosierdzia oraz ekologią ${ }^{34}$. Dykasteria, jako organ Stolicy Apostolskiej, będzie również wyrazem zainteresowania papieża każdym cierpiącym, a w szczególności potrzebującym, chorym i wykluczonym. Ze szczególną troską będzie ona wieloaspektowo wspierała tych, którzy są zmuszeni do opuszczenia ojczyzny lub są jej pozbawieni, a także ofiary wojen, katastrof oraz ofiary współczesnego niewolnictwa i handlu ludźmi, uwięzionych, bezrobotnych i torturowanych ${ }^{35}$.

Według Statutu pracami Dykasterii będzie kierował prefekt, wspierany przez sekretarza i podsekretarza. Sekretarzem i podsekretarzem niekoniecznie musi być osoba duchowna. Kobiety i mężczyźni, jako wierni świeccy pochodzący z różnych części świata i zajmujący się fenomenem współczesnych migracji, mogą być również członkami Dykasterii. Oprócz tego Dykasteria, zachowując normy obowiązujące w Kurii Rzymskiej, posiada konsultorów i urzędników, którymi również mogą być osoby świeckie pochodzące $\mathrm{z}$ różnych krajów ${ }^{36}$.

Dla powołanej przez papieża Franciszka Dykasterii ważne dyspozycje znajdują się w artykule czwartym Statutu, który normuje jej relacje z innymi organami Kurii Rzymskiej. Aż trzy paragrafy podkreślają wagę i określają formy współpracy z Sekretariatem Stanu ${ }^{37}$.

\footnotetext{
${ }^{33}$ Francesco, Statuto del Dicastero per il Servizio dello Sviluppo Umano Integrale, art. 1, par. 2 .

${ }^{34}$ Tamże, art. 1, par. 1 .

${ }^{35}$ Tamże, art. 1 par. 3.

${ }^{36}$ Tamże, art. 2 par. 1-4.

${ }^{37}$ Tamże, art. 4. Par. 1-3: Punktem wyjścia, zgodnie z kompetencjami, jest ścisła współpraca Dykasterii ds. Integralnego Rozwoju Człowieka z Sekretariatem Stanu. Współpraca ta ujawnia się szczególnie w relacjach z poszczególnymi państwami oraz organizacjami międzynarodowymi oraz w publikowanych dokumentach i deklaracjach dotyczących tych relacji i podejmowanych problemów. Przedstawiciele
} 
Oprócz tego nowa Dykasteria, zgodnie ze swoim Statutem, winna utrzymywać ścisłe relacje z Papieską Akademią Nauk Społecznych ${ }^{38}$ oraz z Caritas Internationalis ${ }^{39}$. Dykasteria może powoływać międzynarodowe organizacje realizujące jej cele statutowe oraz jest kompetentna do nadzoru ich działalności ${ }^{40}$.

Dykasteria, czerpiąc moc z Orędzia Chrystusa Pana, winna pogłębiać naukę społeczną Kościoła oraz promować jej znajomość wśród wiernych. Chodzi nie tyle o znajomość jako taką, ile o wprowadzanie jej w praktykę ${ }^{41}$. Zadaniem nowego organu Stolicy Apostolskiej będzie również systematyczne zbieranie i opracowywanie informacji dotyczących sprawiedliwości, pokoju i rozwoju, a także ochrona godności człowieka ${ }^{42}$.

W realizacji wyznaczonych celów Dykasteria ds. Integralnego Rozwoju Człowieka będzie współpracowała z poszczególnymi Konferencjami Biskupów, oferując swoją koordynującą współpracę, by wspólnie promować takie wartości jako sprawiedliwość i pokój oraz ochronę całego dzieła stworzenia ${ }^{43}$. Celem podjęcia wyznaczonych zadań winna ona współpracować również z poszczególnymi Kościołami lokalnymi, w których poprzez wspólnoty parafialne można bezpośrednio docierać do potrzebujących i oferować im niezbędną pomoc $^{44}$.

Zadaniem Dykasterii ds. Integralnego Rozwoju Człowieka jest również wspieranie i koordynacja działalności poszczególnych instytucji katolickich, których zadaniem jest promować godność osoby ludzkiej oraz propagować takie wartości jak sprawiedliwość i pokój

Dykasterii mogą uczestniczyć w delegacjach Stolicy Apostolskiej w spotkaniach międzyrządowych w sprawach dotyczących problemów zleconych Dykasterii.

${ }^{38}$ Tamże, art. 4 par. 4.

${ }^{39}$ Tamże, art. 4 par. 6.

${ }^{40}$ Tamże, art. 6.

${ }^{41}$ Tamże, art. 3 par. 1 .

${ }^{42}$ Tamże, art. 3 par. 2.

${ }^{43}$ Tamże, art. 1 par. 2.

${ }^{44}$ Tamże, art. 3 par. 3 . 
oraz ochronę środowiska naturalnego ${ }^{45}$. Poprzez powołaną Dykasterię Stolica Apostolska pragnie współpracować także z innymi organizacjami i instytucjami pozarządowymi, również niekatolickimi, które promują ogólnoludzkie wartości. Może ona również w imieniu Stolicy Apostolskiej ze względu na wskazane cele prowadzić z instytucjami państwowymi i międzynarodowymi dialog dotyczący współczesnych problemów człowieka, zachowując jednak kompetencje pozostałych organów Kurii Rzymskiej ${ }^{46}$.

Dykasteria powołana przez Franciszka ma za zadanie uwrażliwiać współczesnego człowieka na problemy związane z budowaniem sprawiedliwych stosunków społecznych oraz solidarnością z migrantami i uciekinierami. Mają temu służyć między innymi obchody Światowego Dnia Pokoju, Światowego Dnia Migranta oraz Światowego Dnia Chorych ${ }^{47}$.

Statut Dykasterii powołanej przez Franciszka ustanawiają również trzy komisje od niej zależne i prowadzące działalność w ramach jej struktur. Są to: Commissione per la carità, Commissione per l'ecologia oraz Commissione per gli operatori sanitari. Komisjom tym przewodniczy Prefekt Kongregacji ${ }^{48}$.

\section{Sekcja migrantów i uchodźców w nowej Dykasterii}

Dla wielu życie na migracji staje się szansą awansu społecznego. Inni jednak z przyczyn doznawanej niesprawiedliwości, kulturowo-językowych ograniczeń, braku opieki lekarskiej, dostępu do szkół i rynku pracy, a także ucieczki i wypędzenia oraz wykorzystywania seksualnego, nie mogą odnaleźć się w nowym środowisku osiedlenia. Kościół swoją misję wobec migrantów rozumie przede wszystkim jako obecność przy nich i towarzyszenie im, jak również udzielanie im w miarę potrzeb oraz możliwości niezbędnej pomocy humanitarnej, materialnej, prawnej i duchowej.

\footnotetext{
45 Tamże, art. 3 par. 4.

${ }^{46}$ Tamże, art. 3 par. 5 .

${ }^{47}$ Tamże, art. 3 par. 6 .

${ }^{48}$ Tamże, art. 4 par. 5 .
} 
Stolica Apostolska, zainteresowana losem milionów migrantów, dotychczas czyniła to najpierw poprzez Papieską Komisję ds. Duszpasterstwa Migrantów i Turystów, a później poprzez Papieską Radę ds. Duszpasterstwa Migrantów i Podróżnych. Wobec współczesnych ruchów migracyjnych i tragedii z nimi związanych, zdaniem Ojca Świętego Franciszka, Papieska Rada w dotychczasowym kształcie wyczerpała swoje możliwości. Jej likwidacja w żadnym wymiarze nie oznacza odwrócenia się od współczesnej problematyki ludzi w drodze, ale dla Kościoła powszechnego otwiera nowe zadania i cele, a przede wszystkim możliwości rozeznania i rozwiązywania napotkanych problemów. Troska o wszystkich współczesnych migrantów przewija się zarówno w motu proprio Humanam progressionem, jak i w Statucie powołanej Dykasterii. Zdaniem papieża Franciszka wymaga ona zintegrowanego spojrzenia na każdego migranta, uciekiniera i uchodźcę oraz na każdego, kto „wyruszył w droge”. W nich bowiem, $\mathrm{w}$ ich sytuacji egzystencjalnej i kondycji ich rodzin, skupia się, jak w soczewce, wiele współczesnych problemów, począwszy od degradacji naturalnego środowiska i ogólnego stanu zdrowia ludzkości aż po ograniczony dostęp do medycyny, po handel ludźmi i wyzysk poprzez pracę.

Nowo powołaną Dykasterią kieruje Prefekt ${ }^{49}$, jednak w jej ramach działaniami Kościoła wobec uchodźców i wypędzonych pokieruje ad tempus sam Franciszek ${ }^{50}$. Zdaniem komentatorów decyzja ta ma podkreślić wagę problemów związanych ze współczesną migracją polityczną i przymusową ${ }^{51}$.

${ }^{49}$ Tamże, art. 2 par. 1. Pierwszym prefektem Dykasterii ds. Integralnego Rozwoju Człowieka jest kard. Peter Kodwo Appiah Turkson, dotychczasowy przewodniczący Papieskiej Rady „Iustitia et Pax”.

${ }^{50}$ Tamże, art. 1 par. 4: „Una Sezione del Dicastero si occupa speificamente di quanto concerne i profughi e migranti. Questa sezione è posta ad tempus la guida del Sommo Pontefice che la esercita nei modi che ritiene opportuni”.

${ }^{51}$ www.deon.pl/religia/koscioł+świat/ z życia koscioła/z dnia 7.02.2017 r.: „W nowej dykasterii, pozostającej w fazie tworzenia, jedna $z$ sekcji - również na razie - znajduje się bezpośrednio pod nadzorem Ojca Świętego. Chodzi tu o komórkę dotyczącą spraw migrantów i uchodźców. Odpowiedzialni za nią ojcowie Fabio 


\section{Zakończenie}

Dzieje Kościoła są również historią duszpasterstwa specjalnego na rzecz migrantów. Wielkim świadkiem zatroskania o ludzi w drodze jest konstytucja apostolska Exsul Familia Piusa XII, która swoimi rozwiązaniami w zasadzie zainicjowała dyskusję o migrujących na Soborze Watykańskim II, a w konsekwencji wymusiła wiele nowych rozwiązań, rozpisanych w soborowych i posoborowych dokumentach.

Migracja jest zjawiskiem strukturalnym współczesnego świata. Generuje ona wszystkie problemy współczesnej niesprawiedliwości, wojen i nienawiści. Kumuluje mankamenty służb medycznych oraz nieprzestrzegania podstawowych praw człowieka. Likwidacja czterech dotychczasowych Papieskich Rad podejmujących współczesne problemy społeczne i powołanie Dykasterii ds. Integralnego Rozwoju Człowieka ma wyjść naprzeciw problemom, z jakimi boryka się dzisiaj migrant, niezależnie od wyznania i religii, koloru skóry, poglądów politycznych i języka. Przy zachowaniu prawa do wolności religijnej osoba każdego migranta, dla Kościoła stanowi wyzwanie do dzielenia się z nim swymi dobrami. Przybysz niejednokrotnie wymaga integralnej opieki i wieloaspektowego wsparcia.

Współczesne ruchy migracyjne nabierają szczególnego dynamizmu i przekraczają kryteria dotychczasowych kategoryzacji. Nowa Dykasteria Kurii Rzymskiej ma między innymi podjąć trud integralnego ujęcia fenomenu współczesnej ruchliwości człowieka, jego komponentów i trendów oraz być znakiem koniecznej obecności Kościoła wobec wszystkich, których bezpośrednio lub pośrednio swoimi nurtami porywają współczesne migracje.

\section{Vatican Dicastery for Integral Human Development in service of migrants}

Church history is also the history of a specific pastoral care for migrants. A great witness of concern for the people on road is the Apostolic

Baggio i Michael Czerny, jak podkreślił Prefekt, omawiają wszystko z papieżem i otrzymują instrukcje bezpośrednio od niego". 
Constitution "Exsul Familia" of Pius XII, which in essence, with its solutions, initiated the discussion on migrants during the Second Vatican Council and, consequently, forced many new indications and solutions described in details in conciliar and post-conciliar documents.

While maintaining the right to religious freedom, each migrant poses a challenge to the Church to share with them the goods of the Church. A newcomer often requires an integral care and multifaceted support. A dicastery for. Integral Human Development, appointed on 08.17.2013. is tasked to indicate that migration is a structural phenomenon of the contemporary world. The migrants reflect all the problems of contemporary injustices, wars and hatred, shortcomings of medical services and non-compliance with fundamental human rights. Liquidation of the four Pontifical Councils taking up contemporary social problems and the appointment of the Dicastery is supposed to meet the problems people are facing today, regardless of their creed and religion, skin color, political view and language.

SŁowa KLUCzowe: migrant; Stolica Apostolska; Dykasterie Kurii Rzymskiej; sprawiedliwość; pokój, uciekinierzy; wypędzeni; godność człowieka

Key wORDs: migrant; the Holy See; Roman Curia Dicastery; justice; peace; refugee; expelled; human dignity

\section{Nota o Autorze:}

Ks. DR HAB. WOJCIECH Necel SChr, PROF. UKSW - profesor nadzwyczajny na Wydziale Prawa Kanonicznego UKSW w Warszawie, kierownik zakładu Historii Źródeł i Literatury Prawa Kanonicznego w katedrze Historii Prawa Kanonicznego. 